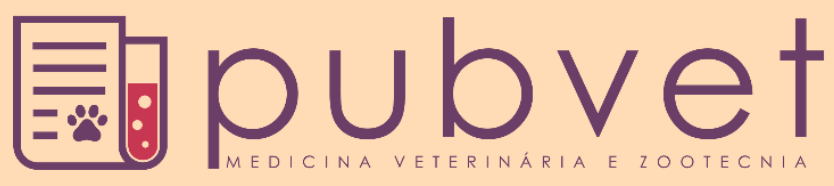

https://doi.org/10.31533/pubvet.v15n06a848.1-10

\title{
Exercise physiology an essential tool in the evaluation of equine athletes. Review
}

\author{
Mylena Dedemo de Figueiredo ${ }^{1 \bullet}$, Guilherme Barbosa da $\operatorname{Costa}^{2^{*}}$, Valeska Rodrigues ${ }^{30}$, \\ Daniel Paulino Junior ${ }^{4} \bullet$
}

${ }^{I}$ Discente Curso de Medicina Veterinária, Universidade de Franca, Franca, SP, Brasil

${ }^{2}$ Médico Veterinário na Empresa JA Saúde Animal

${ }^{3}$ Docente Curso de Medicina Veterinária, Universidade de Franca, Franca, SP, Brasil

${ }^{4}$ Programa de Pós-Graduação em Ciência Animal, Universidade de Franca, Franca, SP, Brasil

*Autor para correspondência, E-mail: guibc14@hotmail.com

\begin{abstract}
The physiological and biochemical responses of the equine athlete, before, during and after physical exercise, are studied in the exercise physiology and, for this to start and muscle contraction occurs, for this it is necessary that the organism produces energy through the production of ATP, which occur in three processes, being alactic or lactic, the alactic process occurs through the metabolism of creatine phosphokinase (anaerobic form) and glucose through the Krebs cycle (aerobic form), whereas the lactic process occurs through the metabolism of lactate. During exercise, in an attempt to reestablish equine parameters, physiological changes occur. The physiology of exercise has been studying, through stress tests, performed on an ergometric treadmill or in the field, ways of obtaining parameters to evaluate the species. This study aimed to evaluate an essential tool that is the physiology of exercise on the physical conditioning of equine athletes, through parameters that observe the performance of these animals. For the methodology, a bibliographic survey of articles was made and directed to the physiology of equine exercise, in addition, necessary tools for the evaluation of equine athletes were addressed, being these neurological, cardiovascular, skeletal, and electrolytic responses. It is concluded that the use of tests for the evaluation of the athletic performance in horses performed by treadmill or in the field together with the physiological responses obtained by the action of exercise and training, is considered a valuable tool for equine sports medicine.
\end{abstract}

Keywords: Assessment, equine, exercise physiology, sports medicine

\section{Fisiologia do exercício uma ferramenta imprescindivel na avaliação de equinos atletas: Revisão}

Resumo. As respostas fisiológicas e bioquímicas do equino atleta, antes, durante e após o exercício físico, são estudadas na fisiologia do exercício e, para que este se inicie e ocorra a contração muscular, para isso é necessário que o organismo produza energia pela produção de ATP, que ocorrem de três processos sendo eles alático ou lático, o processo alático ocorre pela metabolização creatina fosfoquinase (forma anaeróbica) e da glicose pelo ciclo de Krebs (forma aeróbica), já processo lático ocorre pela metabolização do lactato. Durante o exercício, na tentativa de restabelecer os parâmetros dos equinos, ocorrem alterações fisiológicas. A fisiologia do exercício, vem estudando através de testes de esforço, realizados em esteira ergométrica ou a campo, formas de obtenção de parâmetros para avaliação da espécie. Este estudo objetivou avaliar uma ferramenta imprescindível que é a fisiologia do exercício sobre o condicionamento físico de equinos atletas, por meio de parâmetros que observam o desempenho destes animais. Para a 
metodologia foi feito o levantamento bibliográfico de artigos e direcionados a fisiologia do exercício equino, além disso foram abordadas ferramentas necessárias para avaliação dos equinos atletas sendo estas respostas neurológicas, cardiovasculares, músculo esqueléticas e eletrolíticas. Conclui-se que a utilização de testes para a avaliação do desempenho atlético em equinos realizados por esteira ergométrica ou a campo juntamente com as respostas fisiológicas, obtidas pela ação do exercício e do treinamento, é considerada uma valiosa ferramenta para a medicina esportiva equina.

Palavras-chave: Avaliação, equino, fisiologia do exercício, medicina esportiva

\section{La fisiología del ejercicio es una herramienta esencial en la evaluación de los equinos atletas: Revisión}

Resumen. Las respuestas fisiológicas y bioquímicas del equino atleta, antes, durante y después del ejercicio físico, se estudian en la fisiología del ejercicio y, para que éste se inicie y se produzca la contracción muscular es necesario que el organismo produzca energía a través de la producción de El ATP, que ocurre en tres procesos, siendo aláctico o láctico, el proceso aláctico ocurre por medio del metabolismo de la creatina fosfoquinasa (forma anaeróbica) y la glucosa por el ciclo de Krebs (forma aeróbica), mientras que el proceso láctico ocurre por el metabolismo del lactato. Durante el ejercicio, en un intento por restablecer los parámetros equinos, se producen cambios fisiológicos. La fisiología del ejercicio se ha venido estudiando, mediante pruebas de esfuerzo, realizadas en cinta ergométrica o en campo, formas de obtener parámetros para evaluar la especie. Este estudio tuvo como objetivo evaluar una herramienta fundamental que es la fisiología del ejercicio sobre el acondicionamiento físico de los equinos atletas, con de parámetros que observan el desempeño de estos animales. Se realizó un relevamiento bibliográfico de artículos dirigidos a la fisiología del ejercicio equino, además, se abordaron las herramientas necesarias para la evaluación de los atletas equinos, siendo estas respuestas neurológicas, cardiovasculares, esqueléticas y electrolíticas. Se concluye que el uso de pruebas para la evaluación del rendimiento deportivo en caballos realizadas en cinta rodante o en el campo junto con las respuestas fisiológicas obtenidas por la acción del ejercicio y el entrenamiento, se considera una valiosa herramienta para la medicina deportiva equina.

Palabras clave: Evaluación, Equinos, Fisiología del ejercicio, Medicina deportiva

\section{Introduction}

Knowledge about morphology and physiology inherent to the different organ systems of this species is essential for equine sportive exercise. The potential of a good competition horse is always the result of good work by veterinarians, trainers, breeders, and owners, having persistence and seeking new techniques and knowledge (Araújo, 2014).

According to the National Horse Commission, Brazil moves more than seven billion annually with equine activity and has 23 associations of horse producers. As it is a business with great performance, it is necessary to seek new technological solutions in the sustainable use of animals, such as the prevention of over-training, which cause injuries and loss of the animals' useful life (IBGE, 2016).

It is known that intense physical exercise during training, or even competitions, generates in horses; variations in physiological parameters, thus requiring a correct functioning of the nervous, respiratory, cardiovascular and musculoskeletal systems, preserving the body's homeostasis during training (Foss \& Keteyian, 2000).

Some parameters evaluated during exercise direct the veterinarian to know if the intensity and type of effort are appropriate to the athletic capacity of each horse, as the performance of inappropriate physical activities can permanently remove promising horses from the sport (Lima, 2013; Severo, 2010).

Increasingly, the study of exercise physiology in horses is becoming an essential tool in monitoring its intensity, studying themes related to the resistance, strength, and recovery of these animals (Ferraz 
et al., 2010). Currently, the horse's response to training has been called exercise physiology, which is an essential factor for the evaluation of training programs with the objective of contributing to the adaptation of athletes to the stressors present in sports activity (Ferraz et al., 2010). Finally, the objective of this work was to search for literary data on the physiology of exercise and its application in equine sports medicine.

\section{Material and methods}

The methodology used will be the search for articles based on scientific reasoning about Exercise Physiology in horses. The approach will be made by grouping the articles and directing the objective of the study, accompanying the tools to evaluate the equine athletes and their neurological, cardiovascular, musculoskeletal, and electrolytic responses. First, a literature review will be carried out with the virtual library, through the online database of primary sources and journals from the Scientific Electronic Library (SciELO), Virtual Health Library (MEDLINE), websites of the Brazilian Equestrian Federation $(\underline{\mathrm{CBH}, 2018})$.

After the selection of scientific articles, a careful and reflective reading and an analysis of the bibliographic references were carried out, using inclusion and exclusion criteria that meet the objectives of this study, separating them by date of publications and subjects covered, and the thorough analysis of the data will compose the discussion and conclusion of the research.

\section{Exercise physiology}

The physiology of exercise was studied for the first time in the 1920s, with the human being and later, in the 1960s, started studies on it in athlete horses, carried out by the Swedish professor Sune Persson, using high performance treadmills to evaluate the cardiovascular responses of this species ( $\underline{\mathrm{CBH}, 2018)}$.

Currently, exercise physiology is considered an essential tool to monitor the equine species in its training programs, which contribute to the adaptation of equine athletes to the stressors present in physical activity. Legitimate nutritional supplements are also used in order to increase the capacity to perform an effective ergogenic effect (Ferraz et al., 2010).

With the increase in gas exchange by the cardiac and respiratory system, with the objective of increasing the flow of oxygen to all tissues and the consequent removal of carbon dioxide, during exercise, there is a great increase in the functions of muscle bioenergy. Regarding the type of physical effort of the horses, they will suffer muscular, endocrine, metabolic, neurological, and cardiovascular changes, according to the duration of the training and may be prolonged or short. This entire process must respect the individuality of the organisms, as each horse responds differently (Ferraz et al., 2010).

Training with less intensity, that is, lasting 45 minutes induces greater muscle changes, with positive effects on the horse's resistance capacity, however training of greater intensity and shorter duration has a negative effect on its resistance capacity. The moderate and aerobic resistance exercise produces an increase in the aerobic capacity of the muscle to generate Adenosine Triphosphate (ATP). This molecule is the most important carrier of cellular energy and, in insufficient quantities, causes most cells to die quickly (Lindner et al., 2006).

According to Câmara et al. (2007) and Conceição (2018), the more intense physical exercise, the greater the energy demand, that is, in moderate exercise there is a requirement for more glucose consumption by the body, however if the activity was intensified, the oxidative mechanism may not provide enough oxygen to the cells and, consequently, ATP starts to be generated by anaerobic processes involving glycolysis, a fast pathway of ATP synthesis, by the partial breakdown of glucose or muscle glycogen, and the final product of this glycolytic metabolism is lactate, by ionizing lactic acid with proton release hydrogen $\left(\mathrm{H}^{+}\right)$.

The name lactic acidosis is given by the excessive increase in lactate concentrations in the body, in addition to this, other enzymes are evaluated when considering muscle function of the equine athlete, these being the serum concentrations of creatine phosphokinase (CPK) and aspartate aminotransferase (AST), assistants in signaling a drop in performance due to muscle injury (Lindner, 2020). 
The reduction of electrolytes (sodium, potassium, sodium chloride and calcium) during exercise is also responsible for the performance of equine athletes and, according to the exercise, the losses of electrolytes caused by sweating, end up giving variation in the plasma fluid, and the maintenance of blood osmolarity is hampered by the loss, mainly of sodium, potassium and calcium (Martins et al., 2008).

The evaluation of the equine's athletic performance is verified through alterations in muscle function and the presence of myopathies, by the measurement of creatine phosphokinase (CPK), AST and lactate dehydrogenase (LDH). Physical and biochemical changes may also be present since the beginning of training, and a correct assessment is essential, to define whether the animal is fit and whether it has good or bad physical condition (Gramkov \& Evans, 2006).

\section{Physical fitness assessment tests}

In equestrian modalities, the physical effort demand of the horses and the level of physical preparation of the horses is decisive for the achievement of positive results, aiming at the use of biochemical and physiological evaluations to determine the horse's athletic potential (Hodgson et al., 2014).

\section{Physical tests on treadmill}

The use of a treadmill has been advocated for allowing standardization and repeatability, which are basic techniques for carrying out tests that evaluate the performance of equine athletes and allow to develop and establish interactions of the organic systems. It provides physical preparation regardless of the climatic conditions of the place, as they are installed in covered places; makes it possible to monitor in real time the organic functions of the horse, such as heart and respiratory rate (Lindner et al., 2006).

The treadmill mimics conditions of walking, trotting, cantering whatever the desired combination; provides the horse with safe and uniform movements, sliding on a flat surface that provides the integrity of the joints. The treadmill has a control panel that makes it possible to carry out training with acceleration, deceleration, and inclination speed, informing time and distances covered, all controlled according to the need for training and study (Trilk et al., 2002).

According to Câmara et al. (2007) and Conceição (2018), the equipment has a surface molded in a way that favors the "grip" (firmness) and prevents the animal from slipping during training. The "deck" (covered area) gives, together with the surface rubber, a cushioning to the thuds caused by the hitting of the horse's hooves, functioning as a "spring" and reducing impacts. It has a line of three or four gas dampers. These help to avoid the "slap back", which happens when the plates of the floor are pushed against the limbs of the animal. It has a longitudinal limiter and side guards so that the animal's direction of movement does not change; and a safety device that interrupts the movement of the belt (Figure 1).

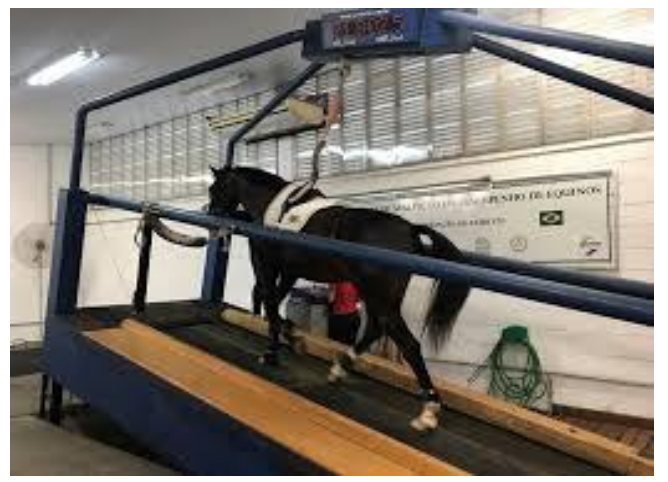

Figure 1. Treadmill for Horses. Source: Conceição (2018)

The use of the treadmill for horses, represented in the image above, has advantages and disadvantages, among the disadvantages are the high cost of setting up an appropriately equipped laboratory, the necessary adjustment period before the test and the distance from the real environment. competitions and training of these animals (Hada et al., 2006). Testing on a treadmill requires the participation of a multidisciplinary team, for the reliability of the results obtained, requiring at least three 
people for the test, one for the containment of the animal close to the head, one to control commands of the treadmill functions and one for position yourself at the rear of the animal (Trilk et al., 2002).

The tests on the treadmill are considered to be rapidly accelerating to $115 \%$ Maximum Oxygen Consumption (VO2máx)., Used in short running animals and progressive exercise tests, which are performed more frequently because they can analyze the animal in submaximal and maximum exercise. The progressive tests on running horses take five minutes of warm-up at four $\mathrm{m} / \mathrm{s}$ and $0 \%$ incline of the treadmill accompanied by five minutes of rest; with the inclination of the treadmill at $10 \%$, the maximum effort test is initiated at $1.8 \mathrm{~m} / \mathrm{s}$, followed by an increasing way up to $11.6 \mathrm{~m} / \mathrm{s}$ and finished at the horse's exhaustion. Maximum oxygen consumption $\left(\mathrm{VO}_{2} \max \right)$, hematocrit peak, heart rate of $200 \mathrm{~b} / \mathrm{min}$ (V200), blood lactate concentration rate of $4 \mathrm{mmol} / 1$ (VLa4), lactate concentration at end of the test, the maximum speed reached during the test, the speed for $\mathrm{VO}_{2} \mathrm{max}$. and the total exercise time (fatigue time). There is a difference with the use of inclines that affects the progression of horses and the speedinclination set alters the workload on the muscles of the forelimbs. After the animal's fatigue, the deceleration proceeds, resuming the starting speed (Conceição, 2018).

\section{Physical field tests}

The physical test in the field can be performed without much sophistication, having a safe response of the metabolic part of the horse in exercise, with regard to HR and blood lactate concentration. This test has the advantage of reproducing familiar conditions of exercise, having the surface, movements and speeds used in the field test well aligned with the command that the horse faces during training and competition (Svedahl \& MacIntosh, 2003).

This field test has measurement limitations when compared to the treadmill test, however it is an accessible tool for many equine breeders. The basis of the test carried out in the field is the HR and blood lactate associated with the speed, having to consider that they are measurements capable of alterations according to the relative humidity of the air and the temperature of the environment (Gomide et al., 2006).

Oxygen measurements (VO2max) are more difficult to perform in the field test, but a test with a portable mask has been tested in the field with positive results. Linear and temporal markers should be placed on the track to assist the rider in maintaining the animal's speed and rhythm to control speed standardization. The use of Global Positioning System (GPS) is also of paramount importance for calculating applied speeds, better to use those that measure speed and HR to facilitate the calculation of V200 and also VLa4 (Trilk et al., 2002). Some requirements must be observed for the functionality of the field test, that is: the warm-up period; the establishment of rates and acceleration distances that will be used in the exercise; test distances and times previously; standardization of sample collection times and observation of environmental conditions.

\section{Main parameters on performance evaluation}

Some parameters are considered fundamental for the assessment of the horse's physical fitness, such as the physiological, hematological, and biochemical parameters that undergo changes due to training. Being the same important for understanding the ability to adapt to the exercise (Brito, 2001).

\section{Heart rate}

The cardiovascular response of an equine should be evaluated for the animal submitted to an intense training, and it can be performed during the practice of exercises, through the use of a specific digital frequency meter for horses, as shown in the image below. The relationship between heart rate (HR) and speed is usually observed for the assessment of athletic potential. Generally, the V160, V180 and V200 represent the speeds at which HR reaches 160, 180 and 200 beats per minute.

The Polar EquineR frequency meter for HR monitoring in the field test is essential for correct measurement, in addition to specifying the intensity of the exercise and analyzing the effects of training and loss of conditioning (Bonomo et al., 2014). 
HR at rest of the horse is related to body surface, metabolic index and autonomic balance specific to the species, race and individual, varying in adult horses between $35-45$ beats / min., And may vary due to excitation during the exam. A warm-up period is always necessary before any exercise, and HR has a positive correlation in submaximal exercises, but it has a small positive correlation in low and medium intensity exercises (Ferraz et al., 2010).

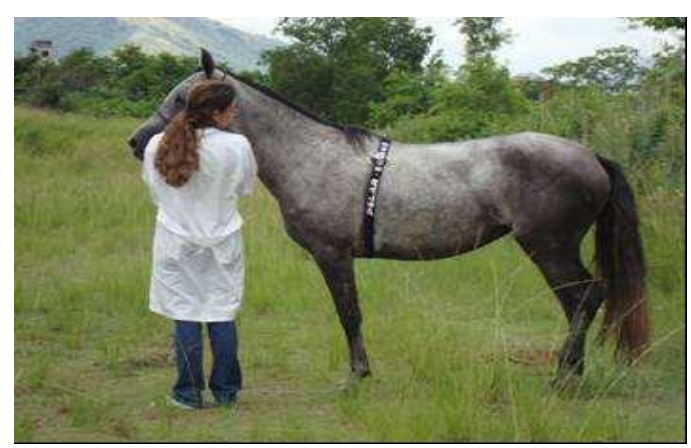

Figure 2. Frequency meter. Source: Public domain.

The HR increases according to the intensity of the exercises until reaching a plateau, being characterized the maximum HR (FCM) between 210-240 beats/min. The HR above the FCM is referred to as maximum exercises and below the FCM as submaximal exercises; that produce adaptive changes in HR during training. The parameter V200 indicated as the speed that results in an HR $=200 \mathrm{bpm}$ is widely used in performance tests and has a high relation with VO2max. and VLa4 (ㅂada et al., 2006).

It is very important for the assessment of physical fitness that HR is measured during exercise using cardiac transmitters, such as the frequency meter. In this way, the effectiveness of training is determined, measurement of the horse's effort during exercise, and the monitoring of cardiac rates of rest and recovery (Hodgson et al., 2014).

\section{Respiratory frequency}

For the good performance of horses, the respiratory system is the limiting factor, as the training does not produce significant adaptive responses as occurs in the cardiovascular and musculoskeletal system. The respiratory system performs essential functions during exercise in addition to the transport of oxygen $\left(\mathrm{O}_{2}\right)$ and carbon dioxide $\left(\mathrm{CO}_{2}\right)$, such as humidification, heating and filtration of inspired air, acid-base regulation, thermoregulation and synthesis, transformation, release, inactivation, and removal of bioactive substances (Ferraz et al., 2009).

Respiratory rate $(\mathrm{RR})$ is the number of respiratory movements per minute $(\mathrm{mpm})$. Horses have a resting RF that ranges from $12-20 \mathrm{mpm}$; some factors increase this frequency, such as high body temperature and pain. In equine training, RF can increase more than $180 \mathrm{mpm}$, and to a certain extent of trot, the animal adopts an RF appropriate to the intensity of the exercise and increases according to the need for oxygen (Ferraz et al., 2010). The RR decreases when the training ceases, consequent to the stop of the locomotor forces that guide the breathing; normally the horse breathes deeply a few times and the FR remains between 60-100 rpm, until the $\mathrm{O}_{2}$ flow is balanced and when reaching this balance, the respiratory response depends directly on the body temperature, if the low temperature the FR declines to the values of rest, if there is a high temperature, the animal will gasp as a heat loss mechanism (Lindner et al., 2006). To analyze whether the horse is in hyperthermia after exercise, RF, the depth of respiratory movements, HR and rectal temperature are observed, taking into account environmental conditions, that is, in hot and humid environments, where skin evaporation is compromised, the heat loss through the respiratory tract represents more than $25 \%$ of the total loss and under normal ambient temperature conditions this loss is between 15-2\% (Araújo, 2014).

\section{Rectal temperature}

The rectal temperature (TR) of the horse varies between $37.2^{\circ} \mathrm{C}$ to $38.6^{\circ} \mathrm{C}$ with average values of $38.0^{\circ} \mathrm{C}$; it is a thermoregulatory system that controls body temperature, changing the heat flow between the animal and the environment. The increase in heat of the animal during exercise depends on its 
duration and intensity, the ambient temperature and humidity, in addition to the hydration of the animal and the thickness of the hair (Foss \& Keteyian, 2000). The TR reaches peaks about 10 minutes after the end of strenuous exercises, reaching $39-40^{\circ} \mathrm{C}$ and decreases between the next 10 to 20 minutes. Exercise causes an imbalance in the thermal balance because the energy used for muscle contraction comes from the conversion of stored chemical energy into mechanical energy, with $75-80 \%$ of the energy released being lost in the form of heat, with an increase in temperature body and inside the muscle. If this heat is not dissipated, the body temperature rises to pathological levels, in addition to the physiological mechanisms that promote heat dissipation are essential for the good performance of the equine athlete. And, of the heat transfer mechanisms such as conduction, convection, radiation and evaporation, the latter is the most important mechanism and evaporation through the respiratory tract (Lindner et al., 2006).

The horse that is under thermal stress shows signs such as: high RF and HR, sweating, apparent peripheral vessels on the body surface and an increase in TR and through this it is possible to assess whether, under conditions of thermal stress, the animals are managing to maintain their temperature within normal limits (Martins et al., 2008).

\section{Lactate concentration}

For the equine athlete, the appropriate generation and use of energy is essential, in addition to having an important function for optimum performance. Glucose is considered an energy source for muscle activity, because when there is an increase in exercise intensity, a large part of this energy is produced through anaerobic glycolysis and consequently lactic acid production occurs. The blood lactate concentration is used as much as the clinical parameters and provides other information about the conditioning of the equine athlete (Ferraz et al., 2010). It is used to assess physical fitness, to indicate the intensity of training of the horse and also to detect adaptations followed by the practice of chronic exercise, the blood lactate concentration (Botteon, 2012).

Lactate metabolism varies between animals, its amount is increased as exercise is intensified. A high concentration of lactate is a consequence of a situation in which the aerobic contribution has become insufficient for the total energy requirements. Lactate and performance are determined by VLa4, which represents the running speed at which the lactate concentration reaches $4 \mathrm{mmol} / \mathrm{L}$ (Gomide et al., 2006). Representing the beginning of the imbalance between the production, removal and metabolization of lactate there is the point of the lactate-speed curve, this point is known as the beginning of the accumulation of lactate in the bloodstream. (Botteon, 2012).

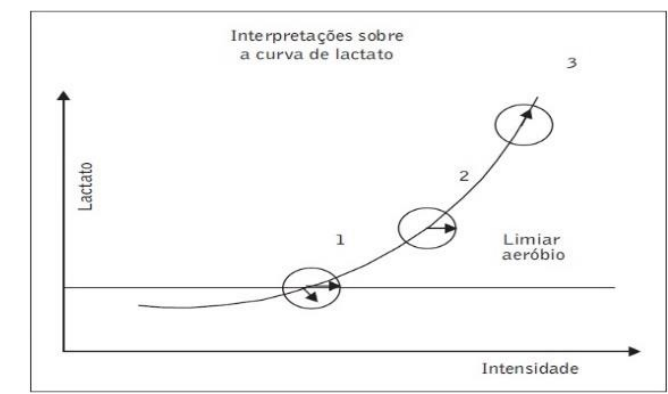

Figure 3. Blood lactate curve. Source: Botteon (2012).

The deviation observed in the lactate-speed curve occurs in horses ranging from 1.5 to $4 \mathrm{mmol} / \mathrm{L}$. The aerobic threshold (LA) is exceeded when working at a higher intensity, which results in rapid accumulation of lactic acid and loss of the anaerobic threshold; this may occur when the working time is too long, depleting energy reserves (Svedahl \& MacIntosh, 2003). LA is the moment of intensity at which lactate begins to accumulate, having a concentration of approximately 3 and $4 \mathrm{mmol} / \mathrm{L}$, which defines two zones, called lower and upper, being an important indicator of efficiency in highperformance sports. Working at a high intensity on the aerobic threshold guarantees a higher speed, without the lactate accumulating and with delay in the appearance of fatigue. In equine athletes, the exercise program at the speed corresponding to $\mathrm{V} 2$, which is the speed at which their lactacidemia 
reaches $2 \mathrm{mmol} / \mathrm{L}$, performed for 45 minutes, three times a week; this program has benefits with regard to the prevention of musculoskeletal injuries (Botteon, 2012).

\section{Glucose}

It is a necessary source of energy for muscle fiber; the anaerobic glucose metabolism corresponds to an essential and fast energy generation mechanism, although it is of low production. Glycolytic activity is regulated by several factors such as the availability of oxygen and concentrations of ATP / ADP, the decrease in this ratio stimulates anaerobic glycolysis by increasing up to 100 times the production of pyruvate molecules. In low or moderate intensity exercises, a considerable part of the pyruvate produced penetrates the mitochondria and participates in the Krebs Cycle (Hodgson et al., 2014).

During exercise, endocrine factors such as insulin, glucagon, adrenaline and norepinephrine act as regulators of glucose levels, that is, a reduction in the molar insulin/glucagon ratio is the primary stimulus for hepatic glycogenolysis, so that there is an increase in blood glucose during low-intensity exercise. Adrenaline can stimulate liver glucose production during physical activity (Di Filippo et al., 2009). During acute muscle strain in horses, insulin suppression leads to an increase in the rate of glycogenolysis to preserve blood glucose concentrations during exercise (Silva, 2008).

\section{Creatine phosphokinase (CK)}

CK is a highly specific enzyme for muscle injuries, found in the skeletal and cardiac muscles, in the kidneys, brain, diaphragm, gastrointestinal tract, uterus and urinary bladder. After the release of CK by muscle cells, it enters the bloodstream directly and moves through the lymph through the interstitial fluid, reversibly causing phosphorylation of adenosine diphosphate (ADP), transforming it into adenosine triphosphate (ATP) available for muscle contraction (Thomassian et al., 2007). CK concentrations may vary according to the horse's ability; the amount of CK in trotting horses shows average concentrations between 18-127 IU/L, with a three to five-fold increase in plasma CK activity equivalent to necrosis or myolysis of approximately $20 \mathrm{~g}$ of the animal's muscle (Thomassian, 2005).

\section{Aspartate aminotransferase (AST)}

This enzyme is responsible for stimulating the reversible transamination reaction of $\mathrm{L}$ aspartate and beta-ketoglutarate in oxalacetate and glutamate, respectively. The permeability of the mitochondrial membrane is associated with the intensity of the exercise, and training can generate an increase in AST activity by up to $30 \%$ compared to untrained animals. Levels greater than $100 \%$ post-exercise can be considered abnormal (Ferraz et al., 2009).

\section{Lactate dehydrogenase (LDH)}

LDH is an enzyme whose function is to catalyze the reversible oxidation of lactate to pyruvate; in erythrocytes its concentration reaches 150 times higher than plasma, being found in most tissues and its evaluation is not specific for muscle injuries (Brito, 2001).

\section{Bicarbonate (HCO3)}

The acid-base balance is significantly altered through physical exercise, as a consequence of the anaerobic metabolism of muscle cells that leads to an increase in lactate concentration. In order to maintain the acid-base balance and prevent $\mathrm{pH}$ variations, compensatory mechanisms are activated, such as the consumption of bicarbonate and reduction of Carbon Gas Pressure (PCO2). The prolonged exercises provoke the loss of chlorine and consequently $\mathrm{HCO}_{3}$ retention, triggering a hypochloremia metabolic alkalosis (Watanabe et al., 2006).

\section{Electrolytes}

The maintenance of body thermoregulation in horses is maintained during prolonged exercise at the expense of fluids and electrolytes that are lost through sweating. Disturbances in the composition of 
electrolytes can lead to an increased risk of injury and several clinical problems, since through sweating the horse loses large amounts of sodium, potassium and chlorine and small amounts of magnesium and calcium (Johson, 1998).

The plasma sodium concentration is linked to the body's water balance, an increase in this electrolyte reflects the excess or deficit of water (hyponatremia or hypernatremia), making it necessary to ensure an adequate supply of sodium in the horse's diet and consumption of salt or electrolyte supplements (Tessele et al., 2013; Thomassian, 2005).

Potassium is related to neuromuscular activities and involved with important organic functions. Horses, when submitted to muscle fatigue, suffer hypokalemia (low amount of potassium); and chlorine losses due to sweating lead to primary changes such as thirst and tiredness (Martins et al., 2008).

\section{Final considerations}

Through this literature review, which reported the view of several authors, on the physiology of exercise in horses and the use of tests for the evaluation of athletic performance, it was possible to gather valuable subsidies and observe the use of fundamental resources to maximize results obtained in equestrian competitions. According to the type of effort, the body of the equine athlete undergoes changes, therefore, the individuality inherent to the different animals must be respected, always assessing the behavior at the time of training and the need that each animal presents.

Finally, it is concluded that the study of exercise physiology in equine athletes is essential to maintain the body's homeostasis during training and competitions; so that injuries, removal of the animal from the sport and even the loss of the animal, are avoided.

\section{References}

Araújo, A. M. S. (2014). Treinamento e desempenho atlético de equinos (Revisão). PUBVET, 8(Art. 1774), 2173-2291. https://doi.org/10.22256/pubvet.v8n18.1774.

Bonomo, C., Michima, L. E. S., Miyashiro, P., \& Fernandes, W. R. (2014). Avaliação ecocardiográfica do desenvolvimento cardíaco de cavalos atletas: comparação entre atividades físicas distintas. Pesquisa Veterinária Brasileira, 34(9), 923-927. https://doi.org/10.1590/s0100$736 \times 2014000900019$.

Botteon, P. T. L. (2012). Lactato na medicina veterinária-atualização conceitual. Revista Brasileira de Medicina Veterinária, 34, 283-287.

Brito, E. L. R. (2001). Análise de características parentais e do produto no desempenho esportivo de cavalos puro sangue de corrida. Universidade Federal do Rio Grande do Sul.

Câmara, S. I. A., Dias, R. V, \& Soto-Blanco, B. (2007). Determinação das atividades séricas de creatina quinase, lactato desidrogenase e aspartato aminotransferase em eqüinos de diferentes categorias de atividade. Arquivo Brasileiro de Medicina Veterinária e Zootecnia, 59(1), 250-252.

$\mathrm{CBH}$ - Confederação Brasileira de Hipismo. O Hipismo no Brasil e a CBH. Disponível em: http://www.cbh.org.br/index.php/cbh/historico.html . Acesso em outubro de 2020

Conceição, C. V. V. (2018). Utilização da esteira ergométrica em plano inclinado no treinamento complementar dos cavalos de salto. Escola de Equitação do Exército.

Di Filippo, P. A., Gomide, L. M. W., Orozco, C. A. G., Silva, M. A., Martins, C. B., Lacerda Neto, J. C., \& Santana, A. E. (2009). Alterações hemogasométricas e eletrolíticas de cavalos da raça árabe durante prova de enduro de $60 \mathrm{~km}$. Ciência Animal Brasileira, 10(3), 840-846.

Ferraz, G. C., Teixeira-Neto, A. R., Lacerda-Neto, J. C., \& Queiroz-Neto, A. (2009). Respostas ao exercício de intensidade crescente em equinos: alterações na glicose, insulina e lactato. Ciência Animal Brasileira, 10(4), 1332-1338.

Ferraz, G. C., Teixeira-Neto, A. R., Pereira, M. C., Linardi, R. L., Lacerda Neto, J. C., \& Queiroz Neto, A. (2010). Influência do treinamento aeróbio sobre o cortisol e glicose plasmáticos em equinos. Arquivo Brasileiro de Medicina Veterinária e Zootecnia, 62(1), 23-29. https://doi.org/10.1590/S0102-09352010000100003. 
Foss, M. L., \& Keteyian, S. J. (2000). Fox: Bases fisiológicas do exercício e do esporte. Guanabara Koogan S.A.

Gomide, L. M. W., Martins, C. B., Orozco, C. A. G., Sampaio, R. de C. L., Belli, T., Baldissera, V., \& Lacerda Neto, J. C. (2006). Concentrações sangüíneas de lactato em eqüinos durante a prova de fundo do concurso completo de equitação. Ciência Rural, 36(2), 509-513. https://doi.org/10.1590/s0103-84782006000200022.

Gramkov, H. L., \& Evans, D. L. (2006). Correlação de ganhos de corrida com velocidade em frequência cardíaca máxima durante um teste de exercício de campo em cavalos de corrida puro-sangue. Equine Veterinary Journal, 36(Suppl.), 118-126.

Hada, T., Ohmura, H., Mukai, K., Eto, D., Takahashi, T., \& Hiraga, A. (2006). Utilização da constante de tempo calculada a partir da recuperação da frequência cardíaca após o exercício por avaliação da atividade autonômica em cavalos. Equine Veterinary Journal, 36, 141-145.

Hodgson, D. R., Mckeever, R. H., \& McGowan, C. H. (2014). Hematology and biochemistry. Elselvier Saunders.

IBGE - instituto brasileiro de geografia e estatística. Censo agropecuário 2016. Disponível em: http://www.sidra.ibge.gov.br/. Acesso em novembro 2020.

Johson, P. J. (1998). Physiology of body fluids in the horse. Veterinary Clinical North American Equine Practice, 14, 1-22.

Lima, R. A. S. (2013). Importância econômica e social da equoterapia. Revista Brasileira de Medicina Equina, 8, 26-27.

Lindner, A. E. (2020). Estado de equilíbrio máximo de lactato durante o exercício no sangue de cavalos. Journal of Animal Science, 88, 2038-2044.

Lindner, A., Signorini, R., Brebo, L., Arn, E., Mancini, R., \& A, E. (2006). Efeito do condicionamento de cavalos com intervalos curtos em alta velocidade nas variáveis bioquímicas em sangue. Jornal Veterinário Equino, 36(Supl.), 88-92.

Martins, C. B., Orozco, C. A. G., Gomide, L. M. W., Ssilva, M. A. G., Christovão, F. G., Queiroz Neto, A., \& Lacerda Neto, J. C. (2008). Efeito do condicionamento atlético sobre o músculo glúteo médio de eqüinos puro sangue arabes. Ars Veterinaria, 23(2), 100-107.

Severo, J. T. (2010). Equoterapia: equitação, saúde e educação. Editora Senac.

Silva, M. A. G. (2008). Concentração de lactato, eletrólitos e hemogasometria em eqüinos não treinados e treinados durantes testes de esforço progressivo. Universidade Estadual Paulista.

Svedahl, K., \& MacIntosh, B. R. (2003). Anaerobic threshold: the concept and methods of measurement. Canadian Journal of Applied Physiology, 28(2), 299-323. https://doi.org/10.1139/h03-023.

Tessele, B., Vielmo, A., Panziera, W., Gomes, D. C., \& Barros, C. S. L. (2013). Miosite eosinofílica em bovinos abatidos para consumo humano. Pesquisa Veterinária Brasileira, 33(11), 1345-1348.

Thomassian, A. (2005). Enfermidades dos cavalos. Livraria Varela.

Thomassian, A., Carvalho, F., Watanabe, M. J., Silveira, V. F., Alves, A. L. G., Hussni, C. A., \& Nicoletti, J. L. M. (2007). Atividades séricas da aspartato aminotransferase, creatina quinase e lactato desidrogenase de eqüinos submetidos ao teste padrão de exercício progressive em esteira. Brazilian Journal of Veterinary Research and Animal Science, 44, 183-190.

Trilk, J. L., Lindner, A. J., Greene, H. M., Alberghina, A. D., \& Wickler, S. J. (2002). Um programa de condicionamento guiado por lactato para melhorar o desempenho de resistência. Equine Veterinary Journal, 34(Supl.), 122-125.

Watanabe, M. J., Thomassian, A., Teixeira Neto, F. J., Alves, A. L. G., Hussni, C. A., \& Nicoletti, J. L. M. (2006). Alterações do pH, da P O2 e da P CO2 arteriais e da concentração de lactato sangüíneo de cavalos da raça Árabe durante exercício em esteira de alta velocidade. Arquivo Brasileiro de Medicina Veterinária e Zootecnia, 58(3), 320-326. https://doi.org/10.5380/avs.v10i1.4086.

Article History:

Received: December 4, 2020

Accepted: January 12, 2021.
License information: This is an open-access article distributed under the terms of the Creative Commons Attribution License 4.0, which permits unrestricted use, distribution, and reproduction in any medium, provided the original work is properly cited. 